\title{
PROTEOLYTIC PROCESSING OF THE ARTERIVIRUS REPLICASE
}

\author{
Eric J. Snijder, Alfred L.M. Wassenaar, Johan A. Den Boon, and \\ Willy J. M. Spaan \\ Department of Virology \\ Institute of Medical Microbiology \\ Faculty of Medicine \\ Leiden University \\ PO Box 320 \\ 2300 AH Leiden, The Netherlands
}

\section{INTRODUCTION}

Arteriviruses are enveloped positive-stranded RNA viruses which belong to the so-called 'coronaviruslike superfamily' ${ }^{1,2,3,4}$. At present, the arterivirus group is comprised of equine arteritis virus (EAV, the prototype of the group), lactate dehydrogenase-elevating virus (LDV), porcine reproductive and respiratory syndrome virus (PRRSV, also known as 'Lelystad virus'), and simian haemorrhagic fever virus (SHFV). Their isometric nucleocapsid core contains a nonsegmented genome of $12.7-15.1 \mathrm{~kb}^{1,5,6}$. The morphological characteristics and genome size of EAV are most comparable to those of togaviruses and flaviviruses. However, the arterivirus replication strategy is similar to that of coronaviruses, which possess $25-31 \mathrm{~kb}$ positive-stranded RNA genomes. Among their common features are the polycistronic genome organization, the same basic gene order $\left(5^{\prime}\right.$-replicase gene-envelope protein genes-nucleocapsid protein gene-3'), and the production of a $3^{\prime}$-coterminal nested set of 4 to 7 subgenomic mRNAs. The $5^{\prime}$ part of the genomes of these viruses is occupied by two large open reading frames (ORF1a and ORF1b) which encode the viral replicase ${ }^{1,5-12}$. Both ORF1a and ORF1b are expressed from the genomic RNA, the latter by means of ribosomal frameshifting ${ }^{1,13}$. The ORF1b products of various members of the coronaviruslike group contain a number of homologous domains ${ }^{1,6,9}$ which indicate that the replicase genes of these viruses are evolutionarily related (Fig. 1).

The large coronaviruslike replicase gene product $(345 \mathrm{~K}-420 \mathrm{~K}$ in arteriviruses, $740 \mathrm{~K}-810 \mathrm{~K}$ in coronaviruses) is a multidomain precursor which is posttranslationally cleaved into smaller functional units. Sequence comparison revealed the presence of multiple putative protease domains in the ORF1a polyproteins of both arteriviruses and coronaviruses ${ }^{1,5,6,10,14}$. One of the coronavirus proteases, responsible for the liberation of the $28 \mathrm{~K} \mathrm{~N}$-terminal replicase product of mouse hepatitis virus (MHV), has 

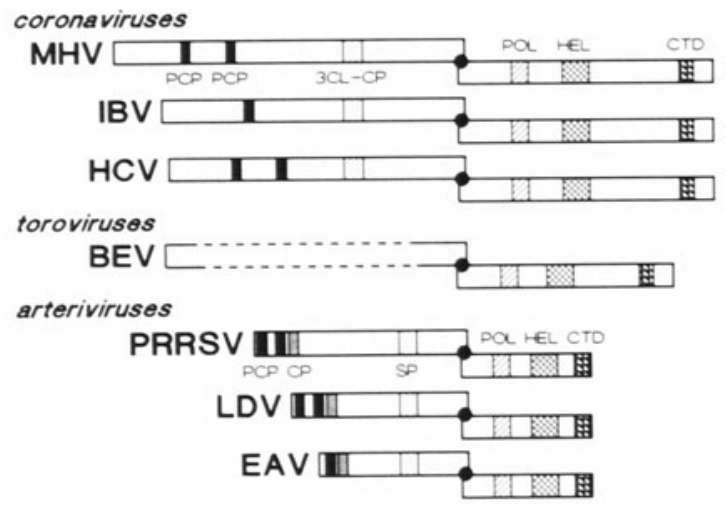

Figure 1. Location of conserved and possibly conserved domains in the replicase proteins of various members of the coronaviruslike superfamily. Abbreviations: PCP, papainlike cysteine protease; $3 \mathrm{CL}-\mathrm{CP}, 3 \mathrm{C}$-like cysteine protease; POL, polymerase motif; HEL, helicase motif; CTD, conserved C-terminal ORF1b domain; CP, cysteine protease; SP, serine protease; IBV, infectious bronchitis virus; $\mathrm{HCV}$, human coronavirus $229 \mathrm{E}$; BEV, Berne torovirus; other virus abbreviations: see text.

recently been characterized ${ }^{15}$. Furthermore, the identification of a number of (putative) coronavirus replicase cleavage products has been reported ${ }^{16-19}$. In the case of the arteriviruses, detailed information on the posttranslational processing of the ORF1a protein has now been obtained. Six proteolytic cleavages and four different viral proteases, all residing within the ORFla protein, have been documented. The various arterivirus protease domains have been characterized in considerable detail. In this brief review, we will summarize our current knowledge of the complex proteolytic processing of the arterivirus replicase ORF1a protein.

\section{PROCESSING SCHEME OF THE EAV ORF1A PROTEIN}

The production of specific antisera, directed against various parts of the EAV ORFla protein, has enabled us to study its proteolytic processing in infected cells and transient expression systems ${ }^{20}$. Western blotting, immunoprecipitation, and pulse-chase experiments revealed that the EAV ORFla protein is subject to (at least) five proteolytic cleavages. These generate processing products of $29 \mathrm{~K}, 61 \mathrm{~K}, 22 \mathrm{~K}, 31 \mathrm{~K}, 41 \mathrm{~K}$, and $3 \mathrm{~K}$, which were named nonstructural protein (nsp) 1 through 6 , respectively ${ }^{20}$ (Fig. 2). Furthermore, a number of intermediate processing products was detected, of which only the smallest three have been identified so far: nsp3456, nsp34, and nsp56 (Fig. 2). After the relatively rapid cleavage of the nsp1/2, nsp2/3, and nsp4/5 junctions, the final processing steps (at the nsp3/4 and nsp5/6 sites) were found to be extremely slow ${ }^{20}$ (Fig. 2 ). This suggests that, as in other viral systems, processing intermediates fulfil specific functions in the arterivirus replication cycle.

\section{THE ARTERIVIRUS PAPAINLIKE CYSTEINE PROTEASES}

Due to its activity in an in vitro translation assay, the papainlike cysteine protease in EAV nsp1, which had been predicted by comparative sequence analysis ${ }^{1}$ (Fig. 3), could be identified and characterized before ORFla protein-specific antisera had been obtained ${ }^{21}$. Residues Cys-164 and His-230 were confirmed as members of the putative catalytic dyad of the EAV nsp 1 protease, which was shown to cleave the nsp $1 / 2$ site extremely rapidly and exclusively in cis $^{21}$. A Gly-Gly dipeptide at position 260-261 was identified as the nsp $1 / 2$ cleavage site $^{21}$. The involvement of the nspl protease in the nsp $1 / 2$ cleavage was recently 
A)

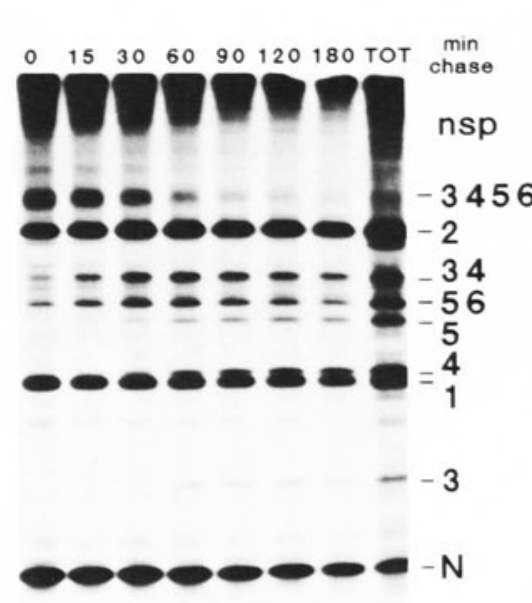

B)

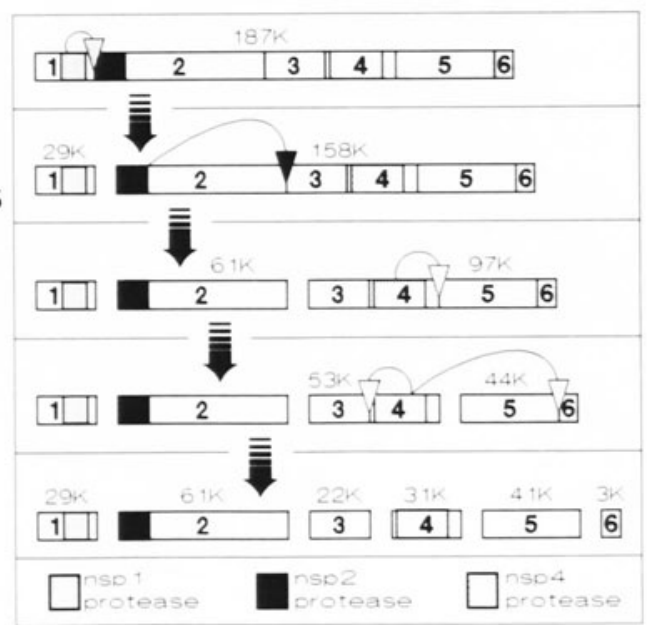

Figure 2. (A) SDS-PAGE of samples from a pulse-chase analysis of EAV ORF1a protein processing in virus-infected cells. A 15 minutes pulse-labeling was followed by chase periods of $0-180$ minutes. The lane indicated with TOT shows the results of a continuous 3 hour labeling. Cells were lysed and viral nsps were immunoprecipitated using a mixture of ORF1a-protein specific antisera ${ }^{20}$. (B) Schematic representation of EAV ORF1a protein processing. The location of the six EAV nsps and the order of proteolytic cleavages is shown. The three EAV proteases and their (putative) relation to cleavage sites are indicated and will be discussed below.

confirmed in an in vivo expression system ${ }^{20}$. The nspl protease appears to have no other function in replicase processing than the liberation of the N-terminal ORFla product. Therefore, it can be added to a rapidly growing family of so-called 'leader' proteases ${ }^{22,23}$, which is comprised of papainlike autoproteases encountered in various positive-stranded RNA virus groups.

In contrast to the C-terminal half of the ORF1a protein and the ORF1b protein, the N-terminal part of the arterivirus ORF1a product is relatively variable, both in size and in sequence ${ }^{6,23}$. Comparative sequence analysis (Fig. 3) and the data obtained with the EAV nspl protease suggested that both PRRSV and LDV might contain an additional PCP domain in the N-terminus of the ORF 1 a protein. Recent experiments have revealed that this is indeed the case ${ }^{23}$. PRRSV and LDV each contain two PCP domains, provisionally named PCP $\alpha$ and $\mathrm{PCP} \beta$, each of which mediates an autoproteolytic cleavage at its own C-terminus, just downstream of the active site His residue. This means that, compared with EAV, these viruses both produce an additional ORF1a protein cleavage product. To avoid differences in nomenclature of highly conserved downstream ORF1aencoded nsps, we have named the two N-terminal products of PRRSV and LDV nspl $\alpha$ and nsp $1 \beta$ (Fig. 5). The sizes of these proteins differ slightly between PRRSV (20K and $27 \mathrm{~K}$ ) and LDV (22K and 26K). Both pairs of predicted active site Cys residues (Cys-76 and Cys-276 in PRRSV, Cys-76 and Cys-269 in LDV) were subjected to site-directed mutagenesis and were shown to be essential for proteolytic activity of a PCP domain ${ }^{23}$. Furthermore, the probable catalytic His residues of the PRRSV PCP $\alpha$ and PCP $\beta$ proteases were identified (His-146 and His-345, respectively). Sequence alignments indicated that the PCP $\beta$ domain corresponds to the EAV nspl PCP domain. An equivalent of the PCP $\alpha$ domain may have been present in $\mathrm{EAV}^{23}$ (Fig. 3). 


\section{THE NSP2 CYSTEINE PROTEASE}

Only the EAV nsp1 protease was found to be active in an in vitro translation system ${ }^{21}$ We therefore contınued our processing analysis using polyclonal rabbit antisera, EAV-infected cells, and an in vivo expression system The latter was based on vaccinia virus recombinant vTF7-3, which produces the T7 RNA polymerase ${ }^{24}$, and transfection of T7 expression plasmids containing (parts of) EAV ORF $1 \mathrm{a}^{20}$

The analysis of both deletions and site-directed mutations in the EAV ORF1a protein indicated that, in addition to the nspl and nsp4 proteases, a third protease was involved in its processing When the nsp1 and nsp4 sequences were deleted from the polyprotein ${ }^{25}$, or when the active site residues Cys-164 and Ser-1184 of the nsp1 and nsp4 proteases, respectively, were mutated ${ }^{25}$, the processing of the $n s p 2 / 3$ cleavage site was not affected Our deletion mutagenesis indicated that, if viral, the protease responsible for cleavage of the nsp2/3 junction should be located within nsp2 or nsp3 Although we have not yet been able to completely exclude the involvement of a host protease in the nsp2/3 cleavage, the data avallable at this moment are most consistent with a proteolytic function for the conserved $\mathrm{N}$-terminus of nsp2 This 100 amino acid domain contains the only nsp2/nsp3 conserved histidine (His-332 in EAV), a residue which is involved in catalysis in most types of proteases A number of additional observations, including the results of site-directed mutagenesis, suggest that Cys-270 and His-332 (Fig 3) may be active site residues of a proteolytic enzyme which represents a novel group of cysteine proteases However, our studies of the nsp2 protease are hampered by the fact that processing of the nsp2/3 junction appears to be very sensitive to changes in nsp2 Large or small deletions in the region which separates the putative protease and its cleavage site all abolished cleavage of the nsp $2 / 3$ site

\section{the arterivirus nsp1 proteases}

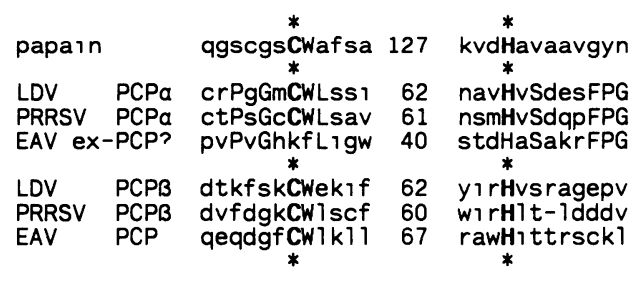

\section{the arterivirus nsp2 proteases}

\begin{tabular}{|c|c|c|c|c|c|c|}
\hline & & * & & * & & \\
\hline $\begin{array}{l}\text { LDV } \\
\text { PRRSV } \\
\text { EAV }\end{array}$ & $\begin{array}{l}C P \\
C P \\
C P\end{array}$ & $\begin{array}{c}\text { gYsPPgDGaCG } 1 \text { hcisAmlN } \\
\text { tYsPPtDGsCGwhv } 1 \text { aA } 1 \mathrm{mN} \\
\text { gYnPPgDGaCGy rcl-AfmN } \\
*\end{array}$ & $\begin{array}{l}42 \\
44 \\
39\end{array}$ & $\begin{array}{l}\text { CPsA iYkldcvnqHWtV } \\
\text { CPnAkYl iklngvHWeV } \\
\text { CPnAkYamicdkqHWrV }\end{array}$ & $\begin{array}{r}11 \\
10 \\
9\end{array}$ & $\begin{array}{l}\text { LapdCIrGvC } \\
\text { LsreCvvGvC } \\
\text { LdesCfrGiC }\end{array}$ \\
\hline
\end{tabular}

\section{the arterivirus nsp4 proteases}

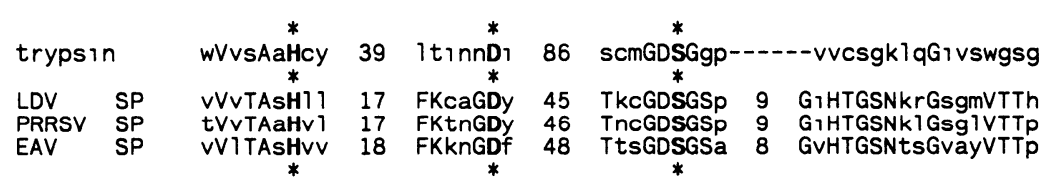

Figure 3. Comparatıve sequence analysıs of the four arterıvirus protease domains Absolutely conserved amino acid residues are shown in capitals Putative active site residues are indicated with asterisks For comparison, the cellular proteases papain and trypsin have been included in the alignment of the nsp 1 and nsp 4 proteases, respectively 
This was also the case when three additional conserved Cys residues in the N-terminal domain of nsp2 were substituted. On the other hand, a $10 \mathrm{~K}$ heterologous insertion in the central part of nsp2 was tolerated ${ }^{20}$ and a separately expressed putative protease domain was shown to be able to induce cleavage of the nsp2/3 site in trans ${ }^{25}$. It appears that a specific folding or posttranslational organization of the nsp2-nsp3 complex is required for proteolysis of the $\mathrm{nsp} 2 / 3$ site. Deleterious effects on the organization of the protease domain and/or the cleavage site region may explain the results obtained with many of our nsp2 mutants carrying amino acid substitutions or deletions.

Both the presence of nsp2 and the cleavage of the nsp2/3 junction appear to be extremely important for processing of the arterivirus ORF1a protein. Preliminary observations from ORF1a in vivo expression experiments indicate that the nsp4 protease is inactive when nsp 2 is absent or when nsp 2 contains mutations which abolish cleavage at the nsp $2 / 3$ junction. Under these conditions, only the nspl protease is able to function normally ${ }^{26}$. To increase our understanding of the role of nsp2 in ORF1 a protein processing, we are currently studying two properties of the nsp2-nsp3 region which may be related to its structure. First, the conserved nsp2 N-terminus, the conserved nsp2 C-terminus, and nsp3 each contain a cluster of conserved cysteine residues ${ }^{20}$, suggesting that disulfide bridges may be involved in the organization of this part of the ORF1a protein. Second, immunofluorescence experiments have revealed that, in infected cells, nsp2 is associated with intracellular membranes ${ }^{26}$.

\section{THE NSP4 SERINE PROTEASE}

Comparative sequence analysis produced a convincing alignment of the arterivirus nsp4 region and the proteases that belong to the superfamily of chymotrypsinlike serine proteases and 3C-like cysteine proteases ${ }^{1,6,27,28}$. A putative catalytic triad of His, Asp and Ser was identified. For EAV, this prediction is now supported by the results from site-directed mutagenesis of two of these putative active site residues, His-1103 and Ser-1184. Their replacement abolishes the processing of the nsp3456 region, but does not affect the production of nsp1 and $n s p 2^{26}$. Together with data obtained from the mutagenesis of putative SP cleavage sites, these results indicate that the nsp3/4, nsp4/5, and nsp5/6 cleavages are all mediated by the nsp 4 protease. Since the SP is able to cleave multiple cleavage sites, albeit with different kinetics (Fig. 2), it is the most likely candidate protease to be involved in the processing of the ORF1b product. The coronavirus 3C-like cysteine protease, which is located at a comparable relative position in the replicase, has recently been shown to be involved in processing of the coronavirus ORF1b protein ${ }^{19}$.

\section{CLEAVAGE SITES}

Six different proteolytic cleavages have now been documented in the various arterivirus ORF1a proteins (Fig. 5) . However, only one cleavage site has been determined by protein sequence analysis, the nsp1/2 site between Gly-260 and Gly-261 in EAV ${ }^{21}$. For the corresponding PRRSV and LDV nsp $1 \beta / 2$ sites, processing is predicted to occur at a Tyr-Gly dipeptide, which is present in both viruses and which can be aligned with the EAV nsp $1 / 2$ cleavage $\operatorname{sit}^{23}$ (Fig. 4). This prediction is supported by the sizes which have been observed for the PRRSV and LDV cleavage products after in vitro translation of cDNA constructs ${ }^{23}$. A suitable cleavage site candidate for the nspl $\alpha / 1 \beta$ site in PRRSV and LDV has not been identified, although a quite accurate estimate of its location was obtained from the same in vitro translation experiments ${ }^{23}$. 

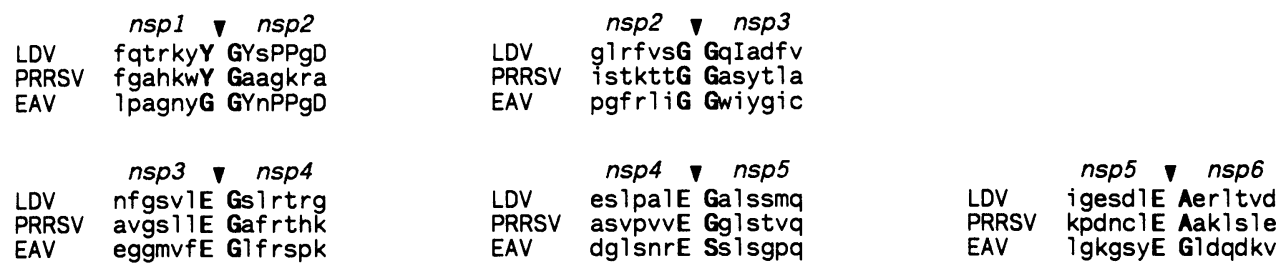

Figure 4. Comparison of possible cleavage sites in arterivirus ORF1a proteins.

The expression of an nsp2 C-terminal deletion mutant ${ }^{25}$ revealed that the EAV nsp2/3 site should be situated near amino acid 825 of the ORF1a protein. A Gly-Gly dipeptide (residues 831-832) appears to be the most attractive candidate (Fig. 4): it is conserved in PRRSV and LDV and it is followed directly by a very hydrophobic domain, which would in this case be the $\mathrm{N}$-terminus of nsp3.

Cleavage site predictions for the arterivirus serine protease were already published before the proteolytic activity of nsp4 and the processing map of the ORF1a protein had been addressed experimentally ${ }^{6}$. On basis of the putative relationship of the nsp 4 protease with the so-called 3C-like cysteine protease group, a set of conserved cleavage sites was proposed which is characterized by a Glu (or Asp) at the P1 position, a Gly (or Ser) at the P1' position, and a bulky hydrophobic residue (e.g. Val, Phe, or Leu) at the $\mathrm{P} 3$ ' position. For the EAV ORF1a protein, SP-directed cleavages at the C-terminal side of aa 1064 (Glu/Gly), 1268 (Glu/Ser), and 1430 (Glu/Gly) were predicted (Fig. 4). We have recently substituted the Glu residues at each of these sites with Pro. Subsequently, these mutations were tested in an ORF1a cDNA construct which was expressed in vivo. Replacement of Glu-1064 abolished cleavage of the nsp3/4 junction ${ }^{26}$. Since this position in the ORF1a protein sequence also corresponds well with the estimated sizes of nsp3 and nsp4, this residue may indeed be located at (or near) the nsp $3 / 4$ cleavage site. This preliminary identification of the nsp3/4 junction is supported by mutagenesis of another conserved Glu residue, located at position 1677 in EAV. When this Glu, which is followed by Gly in EAV and Ala in PRRSV/LDV, was replaced by Pro, the EAV nsp5/6 site was no longer processed ${ }^{26}$. The two putative candidates for the nsp $4 / 5$ cleavage site are more problematic: the estimated $\mathrm{N}$-terminus of nsp5 (44K from the C-terminus of the ORF1 a protein) is in the middle between the two predicted cleavage sites at residues 1268 and 1430 , which are $53 \mathrm{~K}$ and $32 \mathrm{~K}$ from the ORF1a C-terminus, respectively. A Glu 1430 $\rightarrow$ Pro substitution did not have an effect on the generation of any of the currently known ORF1a protein cleavage products ${ }^{26}$. On the other hand, the Glu $1268 \rightarrow$ Pro replacement completely abolished processing of the nsp $4 / 5$ junction $^{26}$. If the nsp $4 / 5$ site would indeed be located at residue 1268 , the sizes of both nsp 4 and nsp56 would differ considerably from the size values estimated from SDS-PAGE: nsp4 would have to be $31 \mathrm{~K}$ instead of $22 \mathrm{~K}$, nsp56 would not be $44 \mathrm{~K}$ but $53 \mathrm{~K}$. Since the Glu1268 $\rightarrow$ Pro substitution also abolished cleavage at the nsp34 junction, this mutation, which is relatively close to the SP active site, may affect the structure of the protease rather than the nsp4/5 cleavage site. Additional experiments, which will also include possible cleavage sites in the ORF1b protein, are now in progress.

\section{ARTERIVIRUS ORF1A PROCESSING SCHEMES AND PRODUCTS}

Our current knowledge of the proteolytic processing of the arterivirus ORF1a protein, and the viral proteases involved in it, is summarized in Fig. 5. The three available arterivirus 


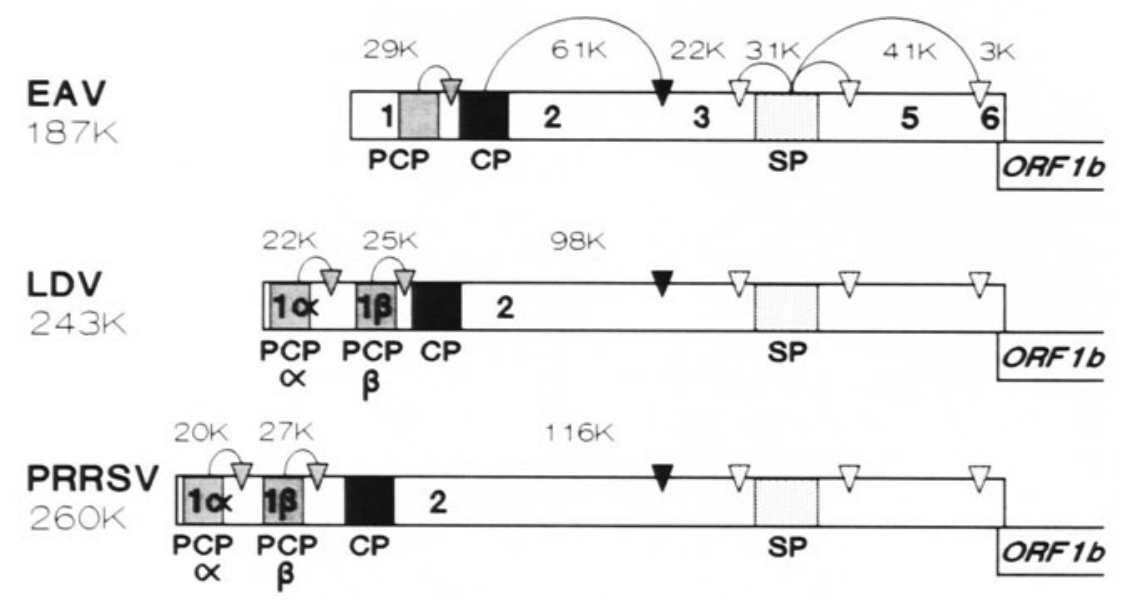

Figure 5. Comparison of the (partially putative) proteolytic processing schemes of the EAV, LDV and PRRSV replicase ORF1a proteins. The position of the four arterivirus proteases and the approximate location of cleavage sites are indicated.

replicase sequences are highly similar in the region which covers the C-terminus of nsp2, nsp3 through 6 , and the ORF1b product ${ }^{6,23}$. We therefore expect that in this part of the replicase the proteolytic processing will be identical or largely similar for EAV, LDV, and PRRSV. The processing of one of the two relatively variable regions, the N-terminal domain of the ORF1a protein containing $\mathrm{PCP} \alpha$, has now been analyzed ${ }^{23}$. This leaves the variable central region of nsp2 to be studied. The high sequence similarity between the three arteriviruses abruptly ends downstream of the putative nsp 2 cysteine protease domain. It is restored about 250 amino acids downstream in EAV, with a domain that contains a cluster of six invariant cysteines. However, the size (600 and 730 amino acids in LDV and PRRSV, respectively) and the sequence of the interlying central region of nsp 2 are variable $e^{6,20}$. The presence of a hydrophobic domain appears to be the only common property. Obviously, we cannot exclude that the proteolytic processing of this region of the PRRSV/LDV ORF1 a proteins differs from that of EAV.

The presence of hydrophobic domains at both sides of the putative main protease, either the SP domain or the 3C-like protease, is a property shared by arteriviruses and coronaviruses. Almost the entire arterivirus nsp3 sequence is hydrophobic. The only hydrophylic domain contains a cluster of conserved cysteine residues. Depending on the exact location of the nsp $4 / 5$ cleavage site (see above), a hydrophobic region downstream of the $\mathrm{SP}$ motif could form a C-terminal hydrophobic domain of nsp4 or an $\mathrm{N}$-terminal hydrophobic region of nsp5. A more downstream hydrophobic part between amino acids 1420 and 1550 in EAV, which is again conserved in PRRSV and LDV, should definitely be within nsp5. Little can be said about the small nsp6. The extreme $\mathrm{C}$ terminus of the ORF1a protein is not very conserved. Although nsp6 itself may be a functional protein, the slow nsp5/6 cleavage could also serve to liberate the ORF1b-encoded proteins from the ORF1ab protein which is produced by ribosomal frameshifting ${ }^{1}$.

\section{CONCLUDING REMARKS}

Our analysis of the processing of the arterivirus replicase has revealed the involvement of (at least) four viral proteases, an unprecedented number among positive-stranded 
RNA viruses Three of these appear to be autoproteases, mediatıng only the liberation of $\mathrm{nsp} 1 \alpha, \mathrm{nsp} 1 \beta$ (or nsp1 in EAV), and nsp2 from the rest of the replicase polyprotein Although a detailed processing map of the coronavirus ORFla protein is not yet available, a general pattern for coronaviruses and arteriviruses seems to emerge The functions encoded from the central region of ORF 1 a to the 3 '-end of ORF $1 \mathrm{~b}$ appear to be the 'core' of the coronaviruslike replicase polyprotein the well-conserved domains (protease - polymerase - helicase C-terminal 'unique' ORF1b domain) are within this area, and only small insertions and deletions in this part of the replicase can be detected within the coronavirus or arterivirus groups In comparable positions, the ORFla proteins of both virus groups contain a domain belonging to the protease superfamily that comprises the chymotrypsin-like and picornavirus 3C-like proteolytıc enzymes Although the predicted catalytıc nucleophile of the coronavirus protease (Cys) differs from that in the arterıvirus proteases (Ser), this domain may still be a remnant from a common ancestor of both virus groups The exchange of Cys for Ser at the active site of the enzyme is considered to be feasible ${ }^{2728}$ Furthermore, the predicted cleavage site sequences are remarkably similar for both virus groups

The N-terminal half of the ORFla protein, on the other hand, is quite variable, suggestıng that species-specific, rather than group-specific, functions have been added to the set of basic functions provided by the 'core' replicase It seems that in both corona- and arterıviruses multiple cysteine autoproteases mediate the processing of this least conserved part of the coronaviruslike replicase

\section{ACKNOWLEDGMENTS}

The experiments on the N-terminal processing of the replicase proteins of LDV and PRRSV were carried out in collaboratıon with Kay Faaberg and Peter Plagemann (Unıversity of Minnesota, Minneapolıs, U S A ) and Janneke Meulenberg (Institute for Anımal Science and Health, Lelystad, the Netherlands), respectıvely The identıfication and characterization of the EAV nsp2 protease was carried out in collaboration with Alexander Gorbalenya (Institute of Polımyelitis and Viral Encephalitıdes, Moscow, Russia, and Purdue University, West-Lafayette, U S A)

\section{REFERENCES}

1 Den Boon, J A , Snıjder E J , Chırnsıde, E D , de Vrıes, A A F , Horzınek, M C , Spaan, W J M Equıne arteritıs virus is not a togavirus but belongs to the coronaviruslike superfamily J Virol 1991,65 29102920

2 Snıjder, E J, Horzınek, M C, Spaan, W J M The coronaviruslıke superfamily Adv Exp Med Biol 1993,342 235-244

3 Snıjder, E J , Horzınek, M C Toroviruses replicatıon, evolution and comparison with other members of the coronaviruslike superfamily J Gen Virol 1993,74 2305-2316

4 Plagemann, PG W, Moennıg, V Lactate dehydrogenase-elevatıng virus, equine arterıtıs virus, and sımıan haemorrhagic fever virus a new group of positıve-stranded RNA viruses Adv Virus Res 1991,91 99192

5 Meulenberg, J J M, Hulst, M M, de Meijer, E J, Moonen, PL J M, den Besten, A, de Kluyver, E P, Wensvoort, G, Moormann, R J M Lelystad virus, the causative agent of porcine epidemic abortion and respiratory syndrome (PEARS), is related to LDV and EAV Virology 1993,192 62-72

6 Godeny, E K, Chen, L, Kumar, S N, Methven, S L, Koonın, E V, Brınton, M A Complete genomic sequence and phylogenetic analysis of the lactate dehydrogenase-elevating virus Virology 1993,194 585596 
7 Boursnell, M E G, Brown, T D K , Foulds, I J, Green, P F, Tomley, F M , Binns, M M Completion of the sequence of the genome of the coronavirus avian infectious bronchitis virus J Gen Virol 1987,68 5777

8 Bredenbeek, P J , Pachuk, C J , Noten, J F H, Charıte, J, Luytjes, W, Weiss, S R, Spaan, W J M The primary structure and expression of the second open reading frame of the polymerase gene of the coronavirus MHV-A59 Nucleic Acids Res 1990,18 1825-1832

9 Snıjder, E J , den Boon, J A, Bredenbeek, P J, Horzınek, M C, Rijnbrand, R, Spaan, W J M The carboxyl-terminal part of the putatıve Berne virus polymerase is expressed by ribosomal frameshiftıng and contains sequence motifs which indicate that toro- and coronaviruses are evolutionary related Nucleic Acids Res 1990, 18 4535-4542

10 Lee, H J , Shieh, C K , Gorbalenya, A E , Koonın, E V, la Monıca, N , Tuler, J , Bagdzhadzhyan, A , Laı, M M C The complete sequence (22 kilobases) of murıne coronavirus gene 1 encoding the putative protease and RNA polymerase Virology 1991,180 567-582

11 Herold, J , Raabe, T, Schelle-Prınz, B , Siddell, S G Nucleotıde sequence of the human coronavirus 229E RNA polymerase locus Virology 1993,195 680-691

12 Bonılla, PJ, Gorbalenya, A E, Weiss, S R Mouse hepatıtıs virus strain A59 RNA polymerase gene ORF la heterogeneity among MHV strains Virology 1994,198 736-740

13 Brierley, I, Diggard, P, Inglis, S C Characterızatıon of an efficient coronavirus ribosomal frameshıftıng signal requirement for an RNA pseudoknot Cell 1989,57 537-547

14 Gorbalenya, A E, Koonın, E V, Donchenko, A P, Blınov, VM Coronavirus genome prediction of putative functional domains in the non-structural polyprotein by comparative amino acid sequence analysis Nucleic Acids Res 1989,17 4847-4861

15 Baker, S C , Shieh, C K, Soe, L H , Chang, M F, Vannier, D M , La1, M M C Identıfication of a domain required for autoproteolytic cleavage of murıne coronavirus gene A polyprotein J Virol 1989,63 36933699

16 Brıerley, I, Boursnell, M E G, Bınns, M M, Bılımorıa, B, Rolley, N J , Brown, T D K, Inglıs, S C Products of the polymerase-encoding region of the coronavirus IBV Adv Exp Med Biol 1990,276 275278

17 Denıson, M R, Zoltıck, PW, Leibowitz, J L , Pachuk, C J , Weiss, S R Identificatıon of polypeptıdes encoded in open reading frame $\mathrm{lb}$ of the putatıve polymerase gene of the murine coronavirus mouse hepatitis virus A59 J Virol 1991,65 3067-3082

18 Denison, M R , Zoltıck, P W, Hughes, S A , Giangreco, B , Olson, A L , Perlman, S , Leibowitz, J L , and Weiss, S R Intracellular processing of the N-terminal ORF1a proteins of the coronavirus MHV-A59 requires multıple proteolytıc events Virology 1992,189 274-284

19 Liu, D X, Brierley, I, Tibbles, K W, Brown, TD K A 100-kılodalton polypeptıde encoded by open reading frame (ORF) $1 \mathrm{~b}$ of the coronavirus infectious bronchitis virus is processed by ORF la products J Virol 1994,68 5772-5780

20 Snıjder, E J , Wassenaar, A L M , Spaan, W J M Proteolytıc processing of the replicase ORF1a protein of equine arteritis virus $\mathrm{J}$ Virol 1994,68 5755-5764

21 Snıder, E J , Wassenaar, A L M , Spaan, W J M The 5' end of the equine arteritis virus replicase gene encodes a papainlike cysteine protease J Virol 1992,66 7040-7048

22 Gorbalenya, A E, Koonın, E V, La1, M M C Putative papain-related thiol proteases of positıve-strand RNA viruses FEBS Lett 1991,288 201-205

23 den Boon, J A , Faaberg, K S , Meulenberg, J J M , Wassenaar, A L M , Plagemann, P G W, Gorbalenya, A E, Snıjder, E J Processing of the N-terminal region of the arterivirus replicase ORFla protein identification of a second papainlıke cysteine protease Submitted

24 Fuerst, T R, Niles, E G, Studier, F W, Moss, B Eukaryotıc transient-expression system based on recombinant vaccinia virus that synthesizes bacterıophage T7 RNA polymerase Proc Natl Acad Scı USA $1986,838122-8126$

25 Snıjder, E J , Wassenaar, A L M, Spaan, W J M, Gorbalenya, A E The arterıvırus nsp2 protease In preparation

26 Snıder, E J , Wassenaar, A L M Unpublıshed observatıons

27 Gorbalenya, A E, Donchenko, A P, Blınov, VM , Koonın, E V Cysteine proteases of positıve strand RNA viruses and chymotrypsin-like serıne proteases a distınct protein superfamily with a common structural fold FEBS Lett 1989,243 103-114

28 Bazan, J F, Fletterıck, R J Viral cysteine proteases are homologous to the trypsin-like family of serıne proteases structural and functional implications Proc Natl Acad Scı USA 1988,85 7872-7876 